\title{
The Importance of Patronage during the Institutionalization of the Companies and the Professional Manager and Entrepreneur Coherence Problem
}

\author{
Dr. Sevim Yılmaz \\ Pamukkale University, Denizli Technical Sciences, Vocational High School, Design Department, Turkiye \\ sevimy@pau.edu.tr \\ Vesile Yılmaz \\ Ministry Of Foreign Affairs, Deputy Directorate General for The Balkans And Central Europe, Turkiye \\ vesile.yilmaz@mfa.gov.tr
}

Doi:10.5901/ajis.2015.v4n1s2p239

\begin{abstract}
When companies start institutionalization, it is inevitable that some difficulties will be faced while advancing with the guidance of the experienced and professional managers under the employer's control. In the operation of this process, as much as the importance of the patronage (the entrepreneur's embracing the control and style of managing), the mangers' (that give account to the entrepreneur) being able to embrace the institution and to have an accord with the boss are also important. It is normal to face some coherence problems and opinion differences between the entrepreneur and the senior manager in the institutionalizing companies. The level and the depth of these are important; moreover, there are things to do to make them understandable. During the institutionalization process, the coherence problems between the professional manager and the entrepreneur can be resolved through mutual effort. In this study, the main problems are faced and the solution suggestions are given.
\end{abstract}

Keywords: Coherence Problems, Institutionalization, Patronage,

\section{Introduction}

Companies are like living beings: they are born, they develop, and die. The eternal one is life itself, the living ones change in time. When the companies are born and come to the developing phase, they should come up with a vision for their customers that they serve as much as their employees and employers. They should improve and rationalize their products continuously as they reach the aims they put as missions. This can only be possible while institutionalizing. The presence of the shared values at the very beginning compared with forming them later in is really important because interpretation and similarities in the approaches ease the agreements, and therefore speeds up the decision making and application of the decision. During the global crisis experienced in our country and around the world, being institutionalized has a benefit for the companies. The ones in the period of institutionalization, it is inevitable that the effect of the entrepreneur and the professional manager coherence on the process is one of the determining factors on the crisis' having positive or negative effects for the companies.

\section{Institutionalization Concept, Its Development and Importance}

Institutionalization has come out as a result of the needs of the administration staff, the needs of professionalism, the sensibility and the enforcement of the public opinion on the topic, the increase in the consciousness levels of the individuals, the rise in the tendencies on protecting the rights and the values, and the changes in the organization structures (Tügiad,1992).

Institutionalization is defined as 'Giving the institution qualification; the process of a behavior, thinking, and belief style's changing into the structures that are valued by the public and historically stable' by the Turkish Language Society Dictionary (Benligiray, S. ,2005).

Institutionalization emphasizes the importance of the psychological, social, and political issues on examining the social events in general, and the organizations in specific. Institutionalization examines the effectiveness of the 
intellectual powers like the rules and the beliefs, differently from the capitalized approaches that look into the role of the material resources like the formation of the production systems for the structure and the operation of the institutions and the management of the sources (Scott,W. R. ,). The definitions done on institutionalization change according to the handling of the structure because the extent of the concept is wide and is not given the same meaning by everyone. The meanings that come out according to the relationship between the institution and the individuals are as follows:

- Institutionalization is defined by the boss or the managers as, even if the employers change, the institutions being able to survive through their bureaucratic management structure.

- The employees see institutionalization as the trust in the institution and they relate it to the institutions skill on motivation the employees, and relate it to the material and the spiritual trust of the employees to the institution.

- The institutions and the individuals that are in relation with the companies measure the institutionalization indicators of it through its being effective and continuous in terms of business, pursuing its rights with them, and its skill of fulfilling the responsibilities it has.

- The customers connect an institutionalized company with the trust on the goods and the services given by the companies, their skill of compensating their mistakes in time, keeping its existence permanent, and the importance it places on the environment.

When the different viewpoints are taken into consideration, institutionalization can be defined as a feature that keeps the institution's existence permanent, that has a bureaucratic management structure that ensures that the goods and the services are of good quality and reliable, and that keeps the systematic procedures and the objective management approach together (Atılgan, T. and Demirel, A. , 1999).

According to Dr. Üzeyir Garih (2007), Institutionalization is to base the things to be done in the institutions into procedures and to systemize them, planning reports that will show the periodic results and presenting them to the directory or to the representatives of the shareholders of the company and therefore letting them know what is going on at the company and to be able to interfere when necessary.

It is not enough to limit institutionalization with the above mentioned things. Since the employers and the employees at the companies are human beings, it is also important to institutionalize the business ethics. Where there is a system and administration quality, the presence of the business ethics is closely related to the human quality. In institutionalization, the system's being established with the necessary ethics rules has a strategic importance for the company. The department that will contribute to the business ethic to be able to institutionalize is the human resources administration department.

\section{The Institutionalization Process and the Indicators of Institutionalization}

For a company that aims to be institutionalized, many factors should be coordinated together. Company's being institutionalized cannot happen only by applying one or several factors like building a good organizational structure or satisfying the clients at the highest rate by producing good and qualified products. At this point, a final idea cannot be reached about a company's being institutionalized or not, without first answering the question, how a company becomes institutionalized. Then, the procedure that the institutionalized companies went through should be analyzed. In one of the vital studies done on institutionalization, it is emphasized that it is not enough but necessary to take precautions for the institution to be able to live without being dependent on specific individuals (Akat, İ. And Atılgan, T. 1992). These precautions are given as:

- $\quad$ The owner family leaves the administration

- Having professional managers in the administration

- Having staff

- Having delegation of management

- Allocating the employees, dividing the capital

- Establishing a foundation, and allocating it

- Writing 'institution/organization' to the title of the company

- Going public

- Conglomerating, establishing a joint stock company

- Making the administration transparent through some regulations

Taking some or all of these precautions is effective while turning into an institution; on the other hand it is not enough. In addition to these, the most obvious signs of becoming an institution include the followings:

- To become public knowledge 
- To create an organizational culture

- $\quad$ To have interactions with environment

- To have business ethics and laws

- To have a systematic and efficient internal organization

In order for an institutionalized company to sustain its presence and maintain its competitive powers, the above mentioned points make sense as long as they come true in a rational way, not just with show off worries. Otherwise, it is possible to come across red tape, difficulty in decision making and an ungainly running system and also not internalized structural reforms may reduce the company's competitive powers, even lead to more desperate situations up until bankruptcy.

The most significant factors affecting institutionalization are as follows: Firm culture, management style, training, aiming at people and organization structure.

Firm culture constitutes an advantage for the business firm to survive in an atmosphere of competition. Every successful company has its own values and philosophical bases to achieve its aims; regarding these it presents its management system and actions. In addition, firm culture can be defined as the accepted quality of a firm that introduces and advertises it to the outside world.

The management style of a firm is shaped according to the expectations of its leaders, top executives and owners.

Although it is claimed in the definitions related to institutionalization that firms sustain their existence without being dependent on persons, this is not possible, but the only thing that can be done is to reduce the dominant self-interests of leading people. While successful companies are making themselves accepted as institutionalized, the effect of a powerful leader is clearly seen. In the companies in our country, Vehbi Koç from Koç Holding, Durmuş Yaşar from Yaşar Holding, Nejat Eczacıbaşı from Eczacıbaşı Holding can be given as examples to such leaders.

In the institutionalized business firms, in service training is of critical importance. Training activities are provided continuously. The company employees and managers are trained during the charge, in seminars, group meetings and occasional social meetings. Since it takes a long time and requires some effort in order for employees to identify themselves with the institution culture, institutionalized companies make less personnel changes compared to other firms and provide long term employment. Also, in institutionalized companies, managers generally start from the first steps, accept the values of the company, internalize the firm culture and then finally becomes from the top executives, therefore, a manager from outside the company is rarely transferred. In this way, commitment to the institution is increased, the institution values have sustainability and institutionalization process comes true.

The organizational structure in institutions is of great importance. That employees know to whom and for what tasks they are responsible is fundamental so that communication can be successful and decision making can be maintained without any complexity. The manager should give importance, whatever size the firm is, to build a systematic hierarchical organization, and to creating an information network. There is not any specific kind of organizational model about institutionalization and it depends on the business scope, management system, economical and social environment.

Today, the opinions of Karl Marks and J. J. Rousseau, the opponents of institutionalization, have lost their importance and it is understood how important persons are in the organizational structure and so the human factor has gained importance. Associations investing in humans treat their employees with more favor and stops regarding them as a factor for production but as a part of the organization. In this way, the participation and creativity of employees in the development of the firms is valued.

\section{The importance of Patronage in Institutionalization}

The objectives of a company is primarily determined by the company owner and it necessitates encouraging and supervising all staff from the top executives to junior levels. It is possible to reach the objectives of the company without being institutionalized, however, organizational identity and acceptance by the society is not something that can be achieved with simple methods.

First of all, it is crucial that the patron has a high level of consciousness and makes himself accepted by the ordinary people, people with low education or low cultural levels as an example with his education, good manners, personal relations, his respect for nature. It is not possible for a company and its internal structure to have an institutional identity before its patron is accepted and respected thanks to his achievements.

The fact that the patron continuously follows and investigates his surrounding, the visions of the competitor institutions, the relationships of his own company and competitors with government agencies and that he takes 
precautions considering how he can improve his own prestige together with his company will make his company regarded as institutionalized by governmental agencies, employees within the institution and outside and customers.

Every company is an establishment, but not an institution. An institution should have an institutional structure and culture. The institutional culture should be shaped by a patron and top executives who are not rigid on communication and decision making norms within the company but flexible enough to sustain innovative company existence.

Patron is the person accommodating various simultaneous qualities such as being an employer, entrepreneur, capital owner and investor and having leadership characteristics. But what other qualities should a patron of a institutionalized or in institutionalization process especially have?! In order to answer this question, it is necessary to foresee at which level the person who has the identity of a patron sociologically can achieve this.

In order for a patron to aim a business firm having an institutional identity, he should meet physiological, safety, love and belonging needs in Maslow's "Hierarchy of Needs". It is also essential to meet the other needs on the following steps, specifically esteem and self actualization and only in this way he can contribute to the process of institutionalization of the company he owns in a conscious and sincere way.

As the business firms grow bigger, the structure of organizations becomes more complicated and that's why it is necessary for the management to be divided into various levels and limits of authority should be defined. This is a step conducted during the progress of institutionalization. Generally, an organizational structure consisting of a senior, middle and junior staff is built. For the senior staff, a management board selected by investors is determined. Senior officials such as chairman, vice chairman, general manager elected by administrative body have the topmost responsibilities. In a situation like this, chairman of the board is the big boss and upmost authority to whom the accounts and explanations are presented.

In a company in the process of institutionalization, the importance of patronage is undeniable and in achieving the responsibilities, the role of the personal objectives set by the big boss leads him to success within the borders of his power and capabilities. In an institutionalized company, since the patron is the manager at the same time, he should know the basic features of the management, implement them and have them implemented. The basic qualities of management activities are as follows (Tokat,B. and Serbetci, D. , 2001):

- Humanistic Quality

- Quality of Having Objectives

- $\quad$ Quality of Being Group

- Collaboration

- Division of labor and specialization

- Rank System (consisting of administrators and the administered)

- Democratic Quality

- Universal Feature (is seen any kind of organized activity in vertical and horizontal dimensions)

- Individualistic quality

- Two-sided progress (Decision and Implementation)

- Creative process (Thinking, Judging, Comparing)

- A process of being communicative

- Mental quality of the management

- Artistic quality of management

The final stage of the management's development in historical process which is examined as modern management period today takes into the "System Approach" and "Contingency Approach". One of the important researches about the Contingency Approach was undertaken by Fredler. With this research, it was put forward that effective leadership style was dependent upon the interaction of situational variables with each other like the clarity of tasks, the authority that the leader owns, the nature of the relationship between leaders and subordinates. That the boss demonstrates an effective leadership in the process of institutionalization will take place depending upon the interaction of situational variables with each other which Fredler put forth.

If patronage is handled in the manner that it forms the main frame in the planning, organizing, directing, coordinating of managerial staff within the body of a company and setting the task boundaries of them in controlling, and in the manner that all this is ensured to be complied with, the presence of institutionalization in that company may be noticed. If the boss frequently and arbitrarily changes the rules that he himself set, and asks the ones in the managerial staff the issues which are out of their missions, he undermines confidence, the staff doing their job confuse their responsibilities and they get to interfere with one another's job; and this makes the institutionalization look like it exists in words but not in deed. For example, the texts copied from European standards have been in practice as ISO 9001 and 
2000 within the TSE scope for 10 years by large and mid-scale enterprises in our country with the guidance of a consulting firm with the purpose of showing that many companies have a high-class management and production. The standard's being adopted and implemented could not be completed with just receiving the certificate. Expectations in many companies raised as if an institutionalization emerged with it but unfortunately, this, indeed, had little effect on the management philosophy of the enterprises and the manners of bosses and managers. The structure's taking on a corporate state in an organization includes a process of maybe 10 or maybe 20 years. Change and transformation barely occur with the business heirs of the next generation who take charge in the management of the company by having education in more different conditions, and sometimes with no chance for it, companies complete their lives.

For example, Deba Inc. in Denizli, which was considered to be institutionalized, completely went bankrupt. Upon becoming a holding, Funika Textile encountered with the danger of extinction along with the global crisis. Even if the institutionalization of a company looks like a supportive concept to sustain its presence, it is unfortunately not a thing to enable the company to continually develop and live.

The boss's predicting the sectoral fluctuations and taking precautions against them, his attention to sustain his coherence with his senior managers, refreshing the trust by respecting mutual expectations are supportive components in the process of a company's institutionalization.

An institutionalized company is, at the same time, an enterprise which considers and enforces the law. The patronage of an institutionalized company must be undertaken by means of fulfilling its legal obligations to not only its senior managers but also all the employees, shareholders and customers meticulously.

\section{Issue of Professional Manager - Entrepreneur Coherence}

In institutionalized companies, the basic issues between the entrepreneur and the senior manager and the solution offers are given in Table 1.

Table 1. The Issues Between the Professional Managers and the Entrepreneurs and Their Solutions in the Process of Institutionalization in Companies

\begin{tabular}{|c|c|}
\hline $\begin{array}{l}\text { Issues Between The Entrepreneur And The Senior } \\
\text { Manager }\end{array}$ & Solution Offers \\
\hline $\begin{array}{l}\text { Differences in interpretation of the decisions taken between } \\
\text { the employer and the professionals in the upper } \\
\text { administration. }\end{array}$ & $\begin{array}{l}\text { To prevent the differences in interpretation of the taken decisions, in the } \\
\text { implementation phase, managers and the employer need to inform each } \\
\text { other about the operations done by working in a coordinated way. }\end{array}$ \\
\hline $\begin{array}{l}\text { Difficulty in applying decisions arising from norm and value } \\
\text { diversity in the implementation phase. }\end{array}$ & $\begin{array}{l}\text { The employer should choose the staff that he will charge in the upper } \\
\text { administration among the individuals who are in the capacity of giving the } \\
\text { best answer to his own expectations to not let the norm and value } \\
\text { diversities occur. }\end{array}$ \\
\hline $\begin{array}{l}\text { Problems in determining the permissible limits in initiative } \\
\text { takeover and using initiative. }\end{array}$ & $\begin{array}{l}\text { About initiative takeover and using of it, both the employer and the } \\
\text { managers have to set the limits of this situation at the very beginning of } \\
\text { the subject. }\end{array}$ \\
\hline Problem of mutual trust to give and undertake duty. & $\begin{array}{l}\text { Tasks should be given and taken respectively by paying attention to the } \\
\text { ascending order of the cost which the risks in giving and taking on tasks } \\
\text { will give birth to. }\end{array}$ \\
\hline $\begin{array}{l}\text { Problems between a male employer and a female manag } \\
\text { that may be occur due to gender by human nature. }\end{array}$ & $\begin{array}{l}\text { For the problems not to occur which could arise depending on gender, } \\
\text { professional approaches must be performed in the workplace and } \\
\text { conversations apart from job-related subjects and private lives of } \\
\text { individuals should not be on the agenda. }\end{array}$ \\
\hline
\end{tabular}

Problems originating from personality, family training, social environment where they grow up and live could happen to be between the boss and the professional manager while the ones originating from gender differences could also be faced. By human nature, the gender factor has an importance in each environment where there are human relations. Even though male and female behaviors are expected to be the same in the presence of events, this occurs differently in reality. Differences in expectations and approaches come about between the male boss and the female manager (Mukhtar, M. S. ,2002). Adaptation problems and their reasons at the workplace are as the following:

1. Sentimentality is in the foreground in women's viewpoint on events, and the difficulty in behaving sensibly in the face of concrete cases results from their temperament.

2. Sexual harassment of male bosses towards the female manager leads to the fact that their personal expectations get ahead of the expectations for the institution itself; this case is one of the common difficulties. 
3. Denying the male and female managers the equality of opportunity for the same work position; once recognized, paying more to the male in terms of income, are the reasons for the trust possessed for the institutions to be damaged from the point of female managers.

4. Adjustment problems originating from the different motivations of the woman and man related to familial and social life with traditional reasons are frequently observed in business life.

How can a good harmony be between the boss and the senior managers? To be able to reply to this question is only related to know and pay attention to the human nature. A good manager can establish a successful dialogue and ensure cooperation by giving attention to his/her boss's requests and responding sincerely to his/her expectations. Who is managed should not be only the manager; a good general manager is one who manages his/her boss well at the same time. A successful senior manager is someone who can receive from his/her boss sincere answers to the questions like "With what can I simplify your works? Without what can I fulfill your requests? What are the aspects that you give importance to?" and find them noteworthy (Garih, U. , 2007).

\section{The Result and the Offers}

Benefits of institutionalization in terms of enterprise can be summarized as follows:

- $\quad$ The company's having a distinctive culture

- The company's being run professionally, and its giving more opportunity to supervision and improving

- The enterprise's success in its own operation field in a long scale, and preserving and increasing its competitive power

- Job satisfaction of the staff's reaching a high level who serve in the managerial and working staff

- A strong structure's being built in the company and preserving the limits of this structure, and forming a collective consciousness thanks to the company culture constituted to improve the structure

Adaptation issues between the professional manager and the entrepreneur can be widely removed with mutual Endeavour in the process of institutionalization. To make it real, it is important for both sides to comprehend the problems, to transmit to each other mutually in meetings, to approach each other's expectations tolerantly and to pay attention to them in practice. Especially, it will simplify the adaptation if the employer gives importance to education and brings his/her own level closer to the ones of the professional managers if he sees himself inferior or superior to the professional managers. It is also valid for the professional managers. If it's not possible, the realization of institutionalization gets interrupted and conflicts continue. As a solution, if the boss doesn't interrupt the operations, does his task of inspection neatly, takes measures to stimulate the managers' motivation to work in his/her institution by creating different environments with a variety of activities, faces some risky situations by taking the offers made to himself/herself into consideration, and follows their results carefully, he can increase the mutual adaptation and the company's success subsequently.

\section{Acknowledgement}

This study was been financed for publication from PAUBAP with project number 2783.

\section{References}

Tokat,B. , Serbetci, D. , İ̧letmecilik Bilgisi, İstanbul 2001.

Atılgan, T. ve Demirel, A. , "Türkiye'deki Tekstil l̇şletmeleri ve Kurumlaşma (Kurumsallaşma) Üzerine Bir Deneme", Tekstil ve Konfeksiyon Dergisi, Sayl: 2, Yıl: 1999, Sf: 79.

Akat, I. ve Atılgan, T. , "Sanayi Işletmelerinde Kurumlaşma ve Şirket Kültürü, TOBB, Ankara 1992.

Benligiray, S. "Organizasyonlarda İş Etiğinin Kurumlaşmasında İnsan Kaynakları Yönetiminin Rolü", Afyon Kocatepe Üniversitesi İktisadi ve İdari Bilimler Fakültesi Dergisi, Cilt: VII, SayI: 1, Haziran 2005, Sf: 81.

Garih, U. , Deneyimlerim V, 2007

İş Ahlakı ve Türkiye'de İ̧̧ Ahlakına Yönelik Tutumlar, Tügiad Yayınları, İstanbul, 1992

Lauterbach, B. and Vaninsky, a. , "Ownership Structure and Firm Performance: Evidence From Israel" , Journal Of Manangement and Governance 3: $189-201,1999$

Mukhtar, M. S. , "Differences in Male and Female Management Characteristics: Astudy of Owner- Manager Busineses", Small Bussines Economicks 18, 289-311, 2002

Scott, W. R. , "Institutional Theory and Organizations", The Institutional Construction Of Organizations, Souge Publications Inc. , London, s: XIII. 